\title{
Substance Abuse in High School Students: Their Self-Efficacy to Avoid Substance Abuse and Related Factors
}

Sultan Uzun ${ }^{1 \oplus}$, Meral Kelleci2ø

'Cumhuriyet University Research and Training Hospital, Department of Emergency Medicine, Sivas - Turkey ${ }^{2}$ Cumhuriyet University, Faculty of Health Sciences, Department of Nursing, Sivas - Turkey

\section{ABSTRACT}

Substance abuse in high school students: their self-efficacy to avoid substance abuse and related factors

Objective: This study aimed at determining high school students' self-efficacy in the prevention of substance abuse and identifying related factors, given that substance abuse, a major health problem both in Turkey and in other countries of the world, is on the increase not only among adolescents but even among primary school students.

Method: The study population comprised 22,623 students (11,210 males, 11,413 females) in 37 high schools in the provincial center of Sivas. The study sample included 911 students ( 485 females, 426 males). The sample size was calculated using a formula for finite population sampling. The study data were collected using a Sociodemographic Characteristics Questionnaire and the Self-Efficacy for Protecting Adolescences from Substance Abuse Scale. In the data analysis, frequency distribution, variance analysis (ANOVA), Student's t test, Chi-square test, logistic regression analysis, and correlation analysis were used.

Results: Of the participating students, $38.7 \%$ reported that they or people around them used a substance. The substances used were cigarettes (32.8\%), alcohol ( $6.8 \%)$, bonsai $(2.1 \%)$, bally $(1.6 \%)$, cannabis $(0.7 \%)$, and ecstasy $(0.4 \%)$. The mean score on the Self-Efficacy for Protecting Adolescences from Substance Abuse Scale students who either used a substance themselves or had people around them who were substance users was $97.7 \pm 19.39$, while the mean score for those who neither used a substance themselves nor had substance users in their environment was $102.24 \pm 18.51(p=0.001)$. The difference between the two groups was statistically significant $(p=0.001)$. In the prevention of substance abuse, participants who were aged 17 years or older, had any illness, studied in a vocational high school, had a broken family, defined themselves as aggressive, had parents with a low education level, had a bad relationship with their family members, were not satisfied with school life, and had low academic achievement were found to have low self-efficacy $(p<0.05)$. This was 1.46 times higher than in subjects who were not at risk of substance use among the members of the age group 17-19. Students with a history of illness were 0.53 times more likely to use drugs than healthy participants.

Conclusion: It was concluded that studies should be carried out to improve self-efficacy to prevent substance abuse among high school students, particularly among those in the at-risk group.

Keywords: Drug abuse, high school students, prevention, self-efficacy

\section{öz}

Lise öğrencilerinde madde bağımlılığı: Madde bağımlılığından korunma konusundaki öz yeterlikleri ve ilişkili faktörler

Amaç: Bu çallşmada Türkiye'de ve dünyada önemli bir sağlık sorunu olan madde bağımlılığının gençler arasında artması, madde kullanım yaşının ilköğretim düzeyine kadar düşmesi nedeniyle, lise öğrencilerinin, madde bağımllığından korunma konusundaki öz yeterliklerinin ve ilişkili faktörlerin belirlenmesi amaçlandı.

Yöntem: Araştırmanın evrenini Sivas ilii Merkez'de bulunan 37 lisedeki 22,623 öğrenci (11,210 erkek, 11,413 kız) örneklemini ise evrenin belli olduğu durumlarda örneklem seçme formülü ile hesaplanan 911 öğrenci (485 kIz, 426 erkek) oluşturdu. Araştırmanın verileri, Kişisel Bilgi Formu ve Ergenler için Madde Bağımlılı̆ından Korunma Öz Yeterlik Ölçeği ile toplandı. Verilerin analizinde Frekans dağılımı, Varyans Analizi, Student's t Testi, Ki-kare testi, Lojistik regresyon analizi ve Korelasyon Analizi kullanıldı.

Bulgular: Öğrencilerin \%38.7'si kendisinde veya çevresinde madde kullanımının olduğunu bildirmiş̧tir. Kullanılan maddeler ise \%32.8 sigara, \%6.8 alkol, \%2.1 bonzai, \%1.6 bally, \%0.7 esrar ve \%0.4 ecstasy olarak belirtilmiştir. Ögrencilerin kendisinde ve çevresinde madde kullanım öyküsü olanların öz yeterlik ölçeği puan ortalaması $97.77 \pm 19.39$ iken, kendisinde ve çevresinde madde kullanım öyküsü olmayanların öz yeterlik ölçeği puan ortalaması $102.24 \pm 18.51$ olup, aradaki fark istatistiksel olarak anlamlıdır ( $p=0.001)$. Madde bağımlilı̆ından korunmada, 17 yaş ve üzeri grupta, herhangi bir hastalığa sahip, meslek lisesinde okuyan, parçalanmış aile yapısı olan, kendini saldırgan olarak tanımlayan, babasının eğitim düzeyi düşük, aile ilişsisi kötü, okul yaşantııından memnun olmayan ve akademik başarısı düşük olanların madde bağımllığından korunmada öz yeterliklerinin düşük olduğu saptanmışıtır $(p<0.05)$. On yedi-19 yaş grubundaki bireylerin madde kullanma riski kullanmayanlara göre 1.46 kez daha fazladır. Hastalık öyküsü olanların madde kullanma riski, kullanmayanlara göre $0.53 \mathrm{kez}$ daha fazladir.

Sonuç: Lise öğrencilerinde madde bağımllığından korunmada öz yeterliğin arttırımasına ve özellikle riskli grubun güçlendirilmesine yönelik çalışmaların yapılmasına gereksinim olduğu görülmüştür. Anahtar kelimeler: Madde kötüye kullanımı, lise öğrencileri, önleme, öz yeterlik

How to cite this article: Uzun S, Kelleci $M$ Substance abuse in high school students: their selfefficacy to avoid substance abuse and related factors. Dusunen Adam The Journal of Psychiatry and Neurological Sciences 2018;31:356-363. https://doi.org/10.5350/DAJPN2018310404

Address reprint requests to / Yazışma adresi: Meral Kelleci,

Cumhuriyet University, Faculty of Health Sciences, Department of Nursing, Sivas, Turkey

Phone / Telefon: +90-346-219-1010/2505

E-mail address / Elektronik posta adresi: meralkelleci@yahoo.com

Date of receipt / Geliş tarihi: December 31, 2017 / 31 Aralık 2017

Date of the first revision letter / ilk düzeltme öneri tarihi: February 14, 2018 / 14 Şubat 2018

Date of acceptance / Kabul tarihi: February 17, 2018 / 17 Şubat 2018 


\section{INTRODUCTION}

A dolescence is the transition period from childhood to adulthood, involving rapid developments in humans' biology, psychology, and social life (1). Because of these rapid changes affecting later life, adolescence is one of the most critical times in the lifespan of an individual. Another reason for its importance is the frequent appearance of behaviors constituting risks for personal and public health. Particular over the last years, substance addiction has become an important individual and social issue with multidimensional effects on the adolescents' health (2-4).

Substance abuse is characterized as a state where the dose of the used substance increases continually, giving up the use of the substance causes withdrawal symptoms, unsuccessful attempts at quitting occur, substance use continues despite obvious damage, a significant amount of time is used in search of the substance, the affected person uses more than planned and is unable to control the substance use $(5,6)$. It is estimated that in the European Union, over 89 million adults or more than one fourth of the population in the age range of 15-64 years tried illegal drugs at least once in their lifetime. Drug use is reported more frequently in men (54.3 million) than in women (34.8 million). The most commonly used drug is cannabis (51.1 million men and 32.4 million women), while far lower lifetime use estimates are reported for cocaine (11.9 million men and 5.3 million women), MDMA (9.1 million men and 3.9 million women), and amphetamines $(8.3$ million men and 3.8 million women) (7). According to data from the Turkish Statistical Institute, in 2015 16.4\% of the Turkish population of $78,741,053$ persons, that is $12,899,667$ persons, made up the age group of 15-24 years (8). Considering that the great majority of drug users begin their habit before reaching the age of 20 , we realize the importance of this risk group in Turkey.

It has been found that adolescents use substances for a variety of reasons, including entertainment, meeting their social and emotional needs, escaping from problems, seeking excitement, or to challenge their environment $(9,10)$. A large number of risk factors preparing the ground for adolescents to smoke, drink, and use drugs have been identified, emphasizing that the presence of one or more of these factors in adolescents creates a high addiction risk $(6,9)$. Studies have shown that substance use in adolescents goes along with risk behavior such as committing crimes, carrying weapons, eloping, early and unprotected sexual activity, suicide attempts, self-harm, violence, and engaging in brawls (1,10-14). Studies examining the environmental risk factors for substance use in adolescents underline the importance of the character and influence of friends $(3,15)$. A particularly prominent risk factor for youths between the ages of 14 and 16 years is the "presence of a substance-using friend"; therefore, in order to prevent young people from taking up a drug habit, it is necessary to develop their competence to "say no" and to make them feel capable to reject any substance they may be offered $(15,16)$.

Self-efficacy is a person's self-assessment and trust to be able to deal with potential future difficulties successfully, a kind of self-confidence that develops through experience over time. Another factor in its development is the observation of others and the awareness of other people's comments. Some studies report that the belief in self-efficacy is also affecting young persons' onset and continuation of substance use $(16,17)$.

It is known that the most appropriate programs to solve the drug use problem are prevention and early intervention (18). Thus it is assumed that in the prevention of young people's drug use, establishing their self-efficacy regarding avoidance of substance addiction is of great importance. For drug addiction programs to be successful, it is necessary to identify the children and youths at risk and to know individual and environmental risk and protective factors for substance use in adolescence (19).

The results of our study are thought to be useful in the creation of programs for the prevention of drug addiction, as we have determined self-efficacy and influencing factors saving high school students from substance addiction. 


\section{METHOD}

This is a cross-sectional descriptive study aimed at an analysis of self-efficacy regarding high school students' protection from substance addiction and factors affecting their efficacy.

The study population consists of the 22,623 students enrolled in 37 high schools in the center of the province of Sivas (11,210 male and 11,413 female), while the sample is made up of 911 students (485 female, 426 male), calculated on the basis of the formula below:

$\alpha=0.05, p=0.03, q=0.97, t=1.96, d= \pm 0.01$

$\left(\mathrm{n}=\mathrm{Nt^{2 }} \mathrm{pq} / \mathrm{d}^{2}(\mathrm{~N}-1)+\mathrm{t}^{2} \mathrm{pq}\right)$

$\mathrm{N}=$ Population size

$\mathrm{n}=$ Required sample size

$\mathrm{p}=$ Frequency of observing the event in question (prevalence)

$q=$ Frequency of not observing the event in question (1-p)

$\mathrm{t}=$ Theoretical value found in the $\mathrm{t}$ table for specific degrees of freedom and the error level obtained

$\mathrm{d}=$ Desired \pm deviation according to the frequency of observing the event

Students from each high school were selected for the study by simple random sampling.

\section{Measures}

Data form: This form was prepared by the researchers in accordance with the literature. It consists of three sections: the first section records the students' sociodemographic characteristics, the second section asks about family and school-related information such as parents' attitudes, satisfaction with school life, and perceived academic success, while the third section includes information about the respondent's substance use, the presence of substance users in their environment, and the kind of substances being used.

Self-Efficacy for Protecting Adolescences from Substance Abuse Scale: This scale was developed by Eker et al. (16) in 2012 to measure the perceived self-efficacy in high school students to protect themselves from substance addiction. Cronbach's alpha coefficient was calculated to be 0.81 . The scale consists of 24 items and 4 subdimensions (16), which are avoiding narcotics or stimulants $(3,5-8,10,11,16,17,19,20,23)$, avoiding narcotics or stimulants under pressure $(18,21,22,24)$, seeking help regarding narcotics or stimulants (12-15), and supporting friends regarding narcotics or stimulants $(1,2,9)$. The scale includes one control question, indicating that information on self-efficacy can be given by oneself. A 5-point Likert-type scale was used to score the instrument. The lowest possible score is 23 points, the highest score 115 points. A high total score can be interpreted to indicate high selfefficacy in avoiding substance addiction (16). In our study, we found a Cronbach's alpha coefficient of 0.89 .

To carry out our research, we received approval from the ethics committee for non-interventional clinical research of Cumhuriyet University (decision no. 2016-05/13). For data collection, after obtaining permission from the Provincial National Education Directorate we visited the selected schools and met with their administration to provide information. The students to be enrolled in the study were given the required explanations and gave their consent verbally.

\section{Data Collection}

Study data were collected by the researcher in the class room, using a simple random number table to select students to be included in the study. It was made sure that no school administrators or teachers were present in the class room. The aim of the study was explained to the students, and they were assured that the data received would remain entirely confidential and was not going to be used in any way outside the study. Therefore, giving correct answers was very important. To encourage the students to give right and reliable answers, forms were collected in closed envelopes, and neither the names of the respondents nor the names of their respective schools were recorded. 


\section{Statistical Analysis}

In analyzing the data, a test for the significance of the difference between the two mean values in the groups independent from the fulfilment of the parametric test assumptions, variance analysis, Tukey's test, chi-square test, logistic regression analysis and correlation analysis were used. Tables show data as arithmetic means \pm standard deviation, number of individuals and percentage, with a level of significance of $\mathrm{p}<0.05$.

\section{RESULTS}

Of the students, $53.2 \%$ were female, $46.8 \%$ male, more than half of them (58.2\%) in the age group 14-16 and $41.8 \%$ in the group $17-19$ years. There were $87.9 \%$ living with their families, and the family income of $42.2 \%$ was between 1,500 and 2,999 TL. No diagnosis of any disease was given to $87.4 \%$ of students. In their self-assessment, $53.8 \%$ described themselves as sociable, $31.5 \%$ as shy, and $7.5 \%$ as aggressive. Of the students, $69.4 \%$ said they were satisfied with their school life, and while $56.9 \%$ reported a good academic success level, $3.7 \%$ said their level was poor. There were $74.2 \%$ living in a nuclear family, $59.9 \%$ had $1-3$ siblings, and while the fathers of $39.0 \%$ had a primary education level, $26.3 \%$ of the fathers were workers. Of the mothers, $56.1 \%$ had a primary education level and $85.8 \%$ were homemakers. Family relations were described as good by $62.5 \%$ and as intermediate by $34.4 \%$ of students.

As many as 353 students (38.7\%) had a history of substance use in their environment, where in $14.6 \%$ of

Table 1: Comparison of mean scores on the SelfEfficacy for Protecting Adolescences from Substance Abuse Scale between substance users and subjects with a history of substance use in their environment

\begin{tabular}{lccc} 
& \multicolumn{3}{l}{ Self-efficacy scale* } \\
\cline { 3 - 3 } Characteristics & Mean & SD & \\
\hline History of drug use: self or in the environment & & & \\
Yes $(\mathrm{n}=558)$ & 102.24 & 18.51 & $\mathrm{t}=3.48$ \\
No $(\mathrm{n}=353)$ & 97.77 & 19.39 & $\mathrm{p}=0.001$ \\
\hline
\end{tabular}

*Self-Efficacy for Protecting Adolescences from Substance Abuse Scale
Table 2: Comparison of Self-Efficacy for Protecting Adolescences from Substance Abuse Scale mean scores with selected general characteristics

\begin{tabular}{|c|c|c|c|}
\hline \multirow{2}{*}{ Characteristics } & \multicolumn{2}{|c|}{ Self-efficacy scale* } & \multirow[t]{2}{*}{ Test/p } \\
\hline & Mean & SD & \\
\hline \multicolumn{4}{|l|}{$\overline{\text { Sex }}$} \\
\hline Female $(n=485)$ & 103.96 & 16.89 & $\mathrm{t}=5.93$ \\
\hline Male $(n=426)$ & 96.54 & 20.40 & $p=0.001$ \\
\hline \multicolumn{4}{|l|}{ Age } \\
\hline$\leq 16$ years $(n=530)$ & 101.53 & 18.68 & $\mathrm{t}=1.94$ \\
\hline $17+$ years $(n=381)$ & 99.04 & 19.31 & $p=0.05$ \\
\hline \multicolumn{4}{|l|}{ Accommodation } \\
\hline Family (n=801) & 100.54 & 19.16 & $\mathrm{~F}=0.929$ \\
\hline Relatives $(n=12)$ & 93.17 & 20.24 & $p=0.395$ \\
\hline Dormitory ( $\mathrm{n}=98)$ & 100.98 & 17.20 & \\
\hline \multicolumn{4}{|l|}{ Family income level } \\
\hline Minimum wage $(n=225)$ & 101.36 & 17.90 & $F=2.66$ \\
\hline $1,500-2,999 \mathrm{TL}(\mathrm{n}=386)$ & 101.16 & 17.78 & $p=0.047$ \\
\hline $3,000-4,999 \mathrm{TL}(\mathrm{n}=220)$ & 100.48 & 20.36 & \\
\hline 5,000 TL and above $(n=80)$ & 94.88 & 22.64 & \\
\hline \multicolumn{4}{|l|}{ History of disease } \\
\hline Yes $(n=115)$ & 96.50 & 21.57 & $\mathrm{t}=2.16$ \\
\hline No $(n=796)$ & 101.07 & 18.51 & $p=0.033$ \\
\hline \multicolumn{4}{|l|}{ Individual self-description } \\
\hline Sociable $(n=490)$ & 101.82 & 18.33 & $F=11.94$ \\
\hline Shy (n=287) & 102.07 & 17.03 & $p=0.001$ \\
\hline Aggressive (68) & 88.68 & 23.91 & \\
\hline Other $(\mathrm{n}=66)$ & 95.92 & 21.50 & \\
\hline \multicolumn{4}{|l|}{ Type of school } \\
\hline${ }^{* *}$ Anatolia high school $(\mathrm{n}=502)$ & 102.79 & 17.34 & $F=7.031$ \\
\hline Science high school $(\mathrm{n}=37)$ & 103.70 & 17.57 & $p=0.001$ \\
\hline Private high school $(\mathrm{n}=36)$ & 98.03 & 22.21 & \\
\hline Vocational high school (n=336) & 96.96 & 20.53 & \\
\hline \multicolumn{4}{|l|}{ Satisfaction with school life } \\
\hline Yes (632) & 102.89 & 17.20 & $\mathrm{t}=5.37$ \\
\hline No (279) & 92.05 & 21.55 & $p=0.001$ \\
\hline \multicolumn{4}{|l|}{ Level of academic success } \\
\hline Poor $(1-3)(n=34)$ & 83.21 & 28.75 & $\mathrm{~F}=17.12$ \\
\hline Intermediate $(4-6)(\mathrm{n}=359)$ & 99.67 & 18.97 & $p=0.001$ \\
\hline Good $(7-10)(n=518)$ & 102.20 & 17.57 & \\
\hline \multicolumn{4}{|l|}{ Family structure } \\
\hline Extended family (n=206) & 99.07 & 20.29 & $\mathrm{~F}=3.438$ \\
\hline Nuclear family ( $\mathrm{n}=676$ ) & 101.25 & 18.20 & $p=0.033$ \\
\hline Family broken up $(n=29)$ & 92.93 & 24.81 & \\
\hline \multicolumn{4}{|l|}{ Father's educational level } \\
\hline Literate $(\mathrm{n}=61)$ & 91.77 & 23.17 & $\mathrm{~F}=5.684$ \\
\hline Primary education $(\mathrm{n}=355)$ & 101.67 & 18.30 & $p=0.001$ \\
\hline High school $(\mathrm{n}=331)$ & 99.78 & 19.09 & \\
\hline Tertiary education $(n=164)$ & 102.62 & 17.62 & \\
\hline \multicolumn{4}{|l|}{ Mother's education level } \\
\hline Illiterate $(\mathrm{n}=53)$ & 103.57 & 16.51 & $F=2.015$ \\
\hline Literate $(\mathrm{n}=77)$ & 95.99 & 21.53 & $p=0.090$ \\
\hline Primary education $(\mathrm{n}=511)$ & 101.10 & 18.66 & \\
\hline High school (n=203) & 100.85 & 18.09 & \\
\hline Tertiary education $(\mathrm{n}=67)$ & 97.48 & 21.93 & \\
\hline \multicolumn{4}{|l|}{ Respondent's family relation } \\
\hline Good (n=569) & 103.30 & 18.01 & $F=21.42$ \\
\hline Intermediate $(n=313)$ & 96.70 & 18.98 & $p=0.001$ \\
\hline Poor $(n=29)$ & 86.38 & 24.00 & \\
\hline
\end{tabular}

* Self-Efficacy for Protecting Adolescences from Substance Abuse Scale ** State-run high 
cases the father, in $15.1 \%$ of cases a friend, and in $2.6 \%$ the respondent was the user. The substance used was cigarettes (32.8\%), alcohol (6.8\%), bonsai $(2.1 \%)$, bally $(1.6 \%)$, cannabis $(0.7 \%)$, and ecstasy $(0.4 \%)$ of the cases.

The mean score on the Self-Efficacy for Protecting Adolescences from Substance Abuse Scale was $100.49 \pm 18.97$ and thus above medium level. The values for the subdimensions were $51.42 \pm 10.81$ for avoiding narcotics or stimulants, $17.45 \pm 3.84$ for avoiding narcotics or stimulants under pressure, $15.37 \pm 4.33$ for seeking help regarding narcotics or stimulants, and $12.41 \pm 2.93$ for supporting friends regarding narcotics or stimulants.

Table 1 shows that there is a significant difference between the mean scores on the self-efficacy scale between students with a history of substance use in their environment $(97.77 \pm 19.39)$ and those who have no history of substance use $(102.24 \pm 18.51, \mathrm{p}=0.001)$.

Table 2 shows the spread of Self-Efficacy for Protecting Adolescences from Substance Abuse Scale mean scores according to selected general characteristics. There is a statistically significant difference by age group, with the participants aged 17 and above having a lower self-efficacy to avoid substance addiction than those aged 16 and below $(p=0.05)$. There is also a significant advantage related to gender in favor of girls $(p=0.001)$. Students carrying any disease, with a low economic status, defining themselves as aggressive, studying in a vocational school, living in a broken home, with a father having a low level of education, and those judging their family relation as poor and their academic success as low have a significantly lower self-efficacy to avoid substance addiction $(p<0.05)$.

As seen in Table 3, substance use risk in the age group 17-19 years was 1.46 times higher and the $95.0 \%$ confidence intervals for the odds ratio of this risk were (1.11-1.92). The substance use risk for students with a disease history was 0.53 times higher than the nonusers'. The 95\% confidence interval for the odds ratio of this risk rose to (0.36-0.79).

\section{DISCUSSION}

Our study found that $38.7 \%$ of all students either had a substance use history themselves or in their environment. The ratio of students from all groups declaring that they used substances was $2.6 \%$. The study by Altintas et al. (20) reported that $1.68 \%$ of students had tried and given up a substance (20). According to the EMCDDA Report (7), it is estimated that in the European Union more than 88 million people or one quarter of the persons between the ages of 15 and 64 years have tried illegal drugs at least once in their lifetime. Data from the Turkish Narcotics and Narcotics Addiction Monitoring Center (TUBIM, 2011) shows that the lifetime prevalence of substance use for persons having used a narcotic at least once in the age group $15-64$ years is $2.7 \%$, in the age group $15-16$ $1.5 \%$ (21). Our results support the findings from other studies $(12,20,21)$. We found that among students with a history of own substance use or substance use in the environment, in $14.6 \%$ of the cases their fathers were using a substance and in $15.1 \%$ a friend. In a study by Erdamar and Kurupinar (23), the father of $21.1 \%$ and a friend in the case of $48.5 \%$ of the students was smoking. It can be said that in prevention programs, particular attention should be given to parents and friends, as they are of great importance as role models.

The substances used according to our study were cigarettes (32.8\%), alcohol (6.8\%), bonsai (2.1\%), bally $(1.6 \%)$, cannabis $(0.7 \%)$, and ecstasy $(0.4 \%)$. A WHOsupported study carried out in America, Canada, and

Table 3: Results of logistic regression for students' substance use status

\begin{tabular}{lcccc} 
Variables * & B & $\begin{array}{c}\text { Standard } \\
\text { deviation }\end{array}$ & p & $\begin{array}{c}\text { O5\% CI } \\
\text { Exp }(\beta)\end{array}$ \\
\hline Age $(17-19$ years $)$ & 0.38 & 0.13 & 0.006 & 1.46 \\
Cases with disease & -0.62 & 0.20 & 0.002 & 0.53 \\
\hline
\end{tabular}

*When substance use status was used as dependent variable and age, school, disease status, paternal education level, maternal education level as independent variables, Forward LR logistic regression analysis found age and disease status to be risk factors. 
European countries found that $15.0 \%$ of 11 -year-old students, $40.0 \%$ of 13 -year-olds, and $62.0 \%$ of 15 -yearolds had smoked at least once in their lifetime (24). A study done by Ogel et al. (25) in 9 provinces of Turkey reported a prevalence of $55.9 \%$ for smoking, $45.0 \%$ for drinking, $4.0 \%$ for cannabis, $5.1 \%$ for stimulants, $3.6 \%$ for heroin, $2.5 \%$ for ecstasy, and $2.7 \%$ for cocaine among high school students.

Studies on potential environmental risk factors for substance use among youths emphasize characteristics and influence of friends. Particularly in the age group 14-16 years, the most effective factor for starting substance use is the "presence of a substance-using friend" $(1,3,11,15,22)$. It is noteworthy that in our study, too, the highest ratio of substance use in the environment of the students was among friends, which suggests that there might be more substance-using students or the potential risk for substance use might be higher. In a study with 400 students, Walther et al. (26) found a significant correlation between alcohol use and peer influence in the USA. As we have seen, our results support the literature. Therefore, there should be more studies including peers in prevention efforts, given that in this age group the peer influence is particularly high.

A study by Akkus (27) found a high rate of smoking and drinking among respondents with low academic success in school, and Yalcin (28) reported that 20.2\% of students with low academic success had at least once in their lives used a substance. In our study, too, we saw a significant difference in the history of own substance use and substance use in their environment among students who were dissatisfied with their school lives, showing an increase in dissatisfaction with school life and a greater risk of substance use with the weakening of the link with their school for any reason. Thus, keeping students active in school by increasing the number of interesting activities may be an effective method for prevention programs, identifying students at risk of substance use early on. Faggiano et al. (29) also mention the importance of providing information about substance addiction in the extracurricular program, assuming that only knowledge can lead to a change in behavior. A study in America shows that extracurricular activities and a good class organization can increase the students' commitment to school (30).

Our study found a significant inter-group difference in self-efficacy mean scores according to the presence and absence, respectively, of a substance use history in their own lives or in their environment. Bandura (31) defined self-efficacy as a person's belief to be able to initiate an action that is effective on events in the environment and to continue until obtaining a result. Self-efficacy does not mean to be proficient, but it stands for a person's trust in his or her own capabilities. A person with low self-efficacy, even when having the skills to confront a certain situation, will not put these capabilities into action. The study by Akkus et al. (27) mentioned above found a mean score on the selfefficacy scale for students in the study group of 88.34 \pm 13.63. After being provided with a peer education program, the students' self-efficacy mean score rose to $92.96 \pm 15.00$ (27), showing that selfefficacy can be increased through training. Thus, developing self-efficacy can be seen as a starting point for preventing students to develop substance addiction that is worth considering.

In our study, we have seen that students of vocational schools, from broken families, with a history of disease, poor family relations, describing themselves as aggressive, being dissatisfied with their school experience and having a low academic success present with a low mean score on the Self-Efficacy for Protecting Adolescences from Substance Abuse Scale. A study by Ramos et al. (32) carried out in New Mexico reported that through interventions at school-based health centers, $73.1 \%$ achieved a change in alcohol consumption, $65.4 \%$ gained self-efficacy in the use of illegal substances, and $63.5 \%$ in the misuse of prescription drugs. The researchers recommended as a result of their work that research to determine emptiness and inconsistencies related to self-efficacy should be increased (32).

Our study used a big sample group, but the data are dependent upon self-report. Other, more objective measures such as a blood analysis for used substances were not used, which can be seen as a limitation of this 
study. In addition, during the application to the National Education Directorate, the removal of some questions from the questionnaire was requested. Therefore, some expressions have been worded indirectly and thus implicitly.

As a result of our study, we have seen that high school students are a risk group for the beginning and continuation of substance use, and we need research into the increase of self-efficacy. It has become clear that especially students with drug users in their environment who have a low self-efficacy for drug avoidance, are of age 17 and above, male, studying at vocational schools, living in broken families, having low academic success, with parents of a low level of education, poor family relations, a history of illness, describing themselves as aggressive and being dissatisfied with their school experience need to be monitored more closely by guidance teachers and school nurses in their institutions.

The most critical period for substance use, considering age and friendship characteristics, is the beginning of high school. Therefore, the Ministry of National Education and the Ministry of Health should concentrate their protection and prevention activities on this age group. Universities and researchers recommend to plan protective and preventive intervention for students in high school and earlier, considering their individual, familial, and school characteristics, and in cooperation with local institutions related to the National Education Directorates, preventive projects should be run in view of the students' family-schoolenvironment particularities.

\begin{tabular}{|c|c|c|}
\hline \multicolumn{2}{|c|}{ Contribution Categories } & \multirow{2}{*}{$\begin{array}{l}\text { Author Initials } \\
\text { M.K., S.U. }\end{array}$} \\
\hline \multirow{3}{*}{ Category 1} & Concept/Design & \\
\hline & Data acquisition & S.U., M.K. \\
\hline & Data analysis/Interpretation & M.K., S.U. \\
\hline \multirow{2}{*}{ Category 2} & Drafting manuscript & M.K., S.U. \\
\hline & Critical revision of manuscript & M.K., S.U. \\
\hline Category 3 & Final approval and accountability & M.K., S.U. \\
\hline \multirow{3}{*}{ Other } & Technical or material support & S.U., M.K. \\
\hline & Supervision & M.K. \\
\hline & Securing funding (if applicable) & N/A \\
\hline
\end{tabular}

Informed Consent: Written consent was obtained from the participants.

Peer-review: Externally peer-reviewed.

Conflict of Interest: Authors declared no conflict of interest.

Financial Disclosure: Authors declared no financial support.

\section{REFERENCES}

1. Mitchell SG, Gryczynski J, O'Grady KE, Schwartz RP. SBIRT for adolescent drug and alcohol use: current status and future directions. J Subst Abuse Treat 2013; 44:463-472. [CrossRef]

2. Erginoz E. The adolescent, substance addiction, and public health. IU Cerrahpasa Medical Faculty Continuous Medical Education Events. Adolescent Health 2. Symposium Series 2008; 63:61-64. (Turkish)

3. Ogel K, Ermagan E, Eke CY, Taner S. A comparison between drug experimenters and non-experimenters regarding their participation to the social activities: Istanbul sample. Journal of Dependence 2007; 8:18-23. (Turkish)

4. Turhan E, Inandi T, Ozer C, Akoglu S. Substance use, violence among university students and some psychological characteristics. Turkish Journal of Public Health 2011; 9:33-44. (Turkish) [CrossRef]

5. American Psychiatric Association. Diagnostic and Statistical Manual of Mental Disorders. Fifth ed., Washington DC: American Psychiatric Association, 2013: 481-491.

6. Ozturk $\mathrm{MO}$, Ulusahin A. Mental Health and Its Disorders: Mental Disorders Related to the Use of Psychoactive Substances. Twelfth ed., Ankara: Pelin Offset Press, 2014, 727. (Turkish)

7. European Monitoring Centre for Drugs and Drug Addiction. European Drug Report 2016. URL: http://www.emcdda. europa.eu/system/files/publications/2637/TDAT16001ENN.pdf Accessed March 3, 2018.

8. Turkish Statistical Institute. Türkiye İstatistik Kurumu, Nüfus İstatistikleri, 2016. URL: tuik.gov.tr/UstMenu. do?metod=temelist. Accessed June 10, 2017. 
9. Akfert SK, Cakici E, Cakici M. Cigarette and alcohol use among university students and its relationship with family problems. Anatolian Journal of Psychiatry 2009; 10:40-47. (Turkish)

10. Alikasifoglu M. Behavioral problems in adolescents. IU Cerrahpasa Medical Faculty Continuous Medical Education Events. Adolescent Health 2. Symposium Series 2008; 63:55-59. (Turkish)

11. Fergus S, Zimmerman MA. Adolescent resilience: a framework for understanding healthy development in the face of risk. Annu Rev Public Health 2005; 26:339-419. [CrossRef]

12. Kara B, Hatun S, Aydogan M, Babaoglu K, Gokalp AS. Evaluation of the health risk behaviors of high school students in Kocaeli. Journal of Child Health and Disease 2003; 46:30-37. (Turkish)

13. Gurol T. Adolescents at risk of substance addiction. IU Cerrahpasa Medical Faculty Continuous Medical Education Events. Adolescent Health 2. Symposium Series 2008; 63:65-68. (Turkish)

14. Toumbourou J, Patton G. Sawyer S, Olsson C, Web-Pullman J, Catalano R, Godfrey C. Evidence-based health promotion: resources for planning. Adolescent Health Development Section, Public Health Division, Department of Human Services, 2000; 2:12.

15. Kubanc Y, Ozmen F. Opinions of schoolmaster and teachers on drug addiction - present situation and on advices (sic) in secondary schools. Turkish Studies International Periodical for the Languages, Literature and History of Turkish or Turkic 2013; 8:357-382. (Turkish)

16. Eker F, Akkus D, Kapisiz O. The development and psychometric evaluation study of self-efficacy for protecting adolescences (sic) from substance abuse scale. Journal of Psychiatric Nursing 2013; 4:7-12. (Turkish) [CrossRef]

17. Yardimci F, Basbakkal Z. A study of validity and reliability of Middle School Self-Efficacy Scale. Anatolian Journal of Psychiatry 2010; 11:321-326. (Turkish)

18. Police Directorate. Combating Trafficking and Organized Crime (TOC), Report 2014. Ankara: TOC Publications. URL: http:// www.kom.pol.tr/Documents/Raporlar/2014tur.pdf. Accessed April 28, 2016. (Turkish)

19. Albayrak S, Balci S. The prevention of drug abuse in young adults. Journal for Training and Research in Nursing 2014; 2:3037. (Turkish)

20. Altintas H, Temel F, Benli E, Cinar G, Geliner O, Gun FA, Kernak A, Kundakci N. The knowledge, opinion and attitudes of the first year medical students about substance dependence. Journal of Dependence 2004; 5:107-114. (Turkish)
21. Police Directorate General. Turkish Drug Report 2012. Ankara: TOC. URL: http://www.sck.gov.tr/oecd/2012\%20Türkiye\%20 Uyuşturucu\%20Raporu.pdf. Accessed April 28, 2016. (Turkish)

22. Arslan HN, Terzi $\bigcirc$, Dabak S, Peksen Y. Substance, cigarette and alcohol use among high school students in the provincial center of Samsun, Turkey. Erciyes Medical Journal 2012; 34:79-84. (Turkish) [CrossRef]

23. Erdamar G, Kurupinar A. The habit of drug addiction and prevalence among the secondary school students: sample of Bartin city. Afyon Kocatepe Journal of Social Sciences 2014; 16:65-84. (Turkish) [CrossRef]

24. World Health Organization. Adolescents: Health risks and solutions. http://www.who.int/en/news-room/fact-sheets/ detail/adolescents-health-risks-and-solutions. Accessed: September 10, 2018.

25. Ogel K, Corapcioglu A, Sir A, Tamar M, Tot S, Dogan O, Uguz S, Yenilmez C, Bilici M, Tamar D, Liman O. Tobacco, alcohol and substance use prevalence among elementary and secondary school students in nine cities of Turkey. Turk Psikiyatri Derg 2004; 15:112-118. (Turkish)

26. Walther CAP, Pedersen SL, Cheong J, Molina BSG. The role of alcohol expectancies in the associations between close friend, typical college student, and personal alcohol use. Subst Use Misuse 2017; 52:1656-1666. [CrossRef]

27. Akkus D, Karaca A, Sener DK, Ankarali H. Incidence of using substances among high school students and affecting factors. Journal of Dependency 2016; 17:139-151. (Turkish)

28. Yalcin M, Essizoglu A, Akkoc H, Yasan A, Gurgen F. Risk Factors Associated with Substance Use Among Dicle University Students. Turkish Journal of Clinical Psychiatry 2010; 12:125133. (Turkish)

29. Faggiano F, Minozzi S, Versino E, Buscemi D. Universal schoolbased prevention for illicit drug use. Cochrane Database Syst Rev 2014;12. [CrossRef]

30. McNeely CA, Nonnemaker JM, Blum RW. Promoting school connectedness: evidence from the National Longitudinal Study of Adolescent Health. J Sch Health 2012; 72:138-146. [CrossRef]

31. Bandura A. Self-Efficacy: the Exercise of Control. New York: Freeman, 1997, 71-81.

32. Ramos MM, Sebastian RA, Murphy M, Oreskovich K, Condon TP. Adolescent substance use: assessing the knowledge, attitudes, and practices of a school-based health center work force. Subst Abus 2017; 38:230-236. [CrossRef] 